15(5). - P. 433-446. DOI: 10.1111/mpp.12116.

4. Justesen, A.F. The recent history of Puccinia striiformis f. sp. tritici in Denmark as revealed by disease incidence and AFLP markers / A.F. Justesen, C.J. Ridout, M.S. Hovmøller // Plant Pathology. - 2002. - V. 51. - P. 13-23.

5. Milus, E.A. Evidence for increased aggressiveness in a recent widespread strain of Puccinia striiformis f. sp. tritici causing stripe rust of wheat / E.A. Milus, K. Kristensen, , \& M.S. Hovmøller / Phytopathology. - 2009. - V. 99(1). - P. 89-94. DOI: 10.1094/PHYTO-99-1-0089).

6. McNeal F. H. A uniform system for recording and processing cereal research data / F. H. McNeal, C. F Konzak, E. P. Smith, W. S. Tate, T. S. Russell / U.S. Dept. Agric., Agric. Res. Serv, 1971. - ARS 34-121. - 42 pp.

7. McIntosh, R.A. Catalogue of gene symbols for wheat: 2005 supplement R.A. McIntosh1, K.M. Devos2, J. Dubcovsky3, W.J. Rogers4, C.F. Morris5, R. Appels6, and O.D. Anderson. - 2005. Режим доступа:

https://shigen.nig.ac.jp/wheat/komugi/genes/macgene/supplement2005.pdf

DOI 10.18699/GPB2020-73

\title{
Создание исходного материала для селекции в Омском ГАУ с использованием синтетической пшеницы
}

Шаманин В.П. ${ }^{{ }^{*}}$, д.с.-х.н., профессор; Потоикая И.В. ${ }^{l}$, к.с.-х.н., доиент; Шепелев С.С. ${ }^{1}$, к.с.-х.н., зав. лаб.; Чурсин А.С. ${ }^{1}$, зав. лаб.; Пожерукова В.Е. к.б.н., н.с.; Гладких М.С. ${ }^{1}$, к.с.-х.н., н.с., Моргунов А.И. ${ }^{2}$ к.с.-х.н., адьюнктпреподаватель.

${ }^{1}$ ФГБОУ ВО Омский ГАУ, Омск, Россия,

${ }^{2}$ Университет штата Вашингтон, Пулман, США.

*e-mail:vp.shamanin@omgau.org

Проведена фенотипическая оценка исходного материала яровой мягкой пшеницы, полученного на основе гексаплоидной синтетической пиеницы с геномом Aegilops tauschii селекции CIMMYT в условиях южной лесостепи Западной Сибири. Показана селекционная ценность линий с генетическим материалом синтетической пшеницы для повышения урожайности и качества зерна сортов пиеницы.

Ключевые слова: синтетическая пшеница, признаки продуктивности растения, качество зерна, КАSP-маркеры.

\section{Creation of initial material for breeding in Omsk SAU on the basis of synthetic wheat}

Shamanin Vladimir Petrovich ${ }^{1}$, Pototskaya Inna Vladimirovna ${ }^{l}$, Shepelev Sergey Sergeevich $^{l}$, Chursin Aleksandr Sergeevich ${ }^{l}$, Pozherukova Violetta Evgenievna ${ }^{l}$, Gladkih Marina Sergeevna ${ }^{l}$, Morgunov Alexey Ivanovich ${ }^{2}$ 
${ }^{1}$ Omsk State Agrarian University, Omsk, Russia,

${ }^{2}$ Washington State University, Pullman, USA.

A phenotypic and genotypic assessments of the initial material of spring bread wheat obtained on the basis of hexaploid synthetic wheat with the genome of Aegilops tauschii from CIMMYT under conditions of the southern forest-steppe of Western Siberia were carried out. The breeding value of lines with the genetic material of synthetic wheat for increasing of wheat varieties yield and grain quality was shown.

Key words: synthetic wheat, traits of plant productivity, grain quality, KASP-markers.

Первые попытки интродукции генетического материала в геном мягкой пшеницы от диких сородичей были предприняты в 1940-х гг. в Японии и США [7, 8]. Вид Ae. tauschii широко используется в селекционных программах мягкой пшеницы во многих странах мира для расширения генотипического потенциала сортов пшеницы по устойчивости к биотическим и абиотическим стрессовым факторам. В 1980-х гг. в СІММҮТ стартовал проект по созданию синтетической пшеницы с геномом Ae. tauschii и к настоящему моменту получено более 1524 синтетических форм, которые вовлечены в гибридизацию с коммерческими сортами пшеницы, и имеют большую селекционную ценность как генетический ресурс новых аллелей генов [5]. В Омском ГАУ, начиная с 2016 г. в рамках реализации проекта РНФ, ведется работа по изучению набора 124 синтетических линий с геномом $A e$. tauschii селекции CIMМYТ и университета Киото $[1,2,6]$.

Цель исследований - фенотипирование и генотипирование линий, полученных на основе синтетической пшеницы, в условиях южной лесостепи Западной Сибири.

Материал и методы исследований. На опытном поле Омского ГАУ в 2016-2018 гг. изучены 124 синтетические линии селекции СІММҮТ и университета Киото (Япония), созданные в результате гибридизации сортов твердой пшеницы с образцами Ae. tauschii различного эколого-географического происхождения (Иран, Дагестан, Азербайджан, Туркменистан, Кыргызстан, Индия).

В 2019 г. в СП-1 изучено 147 линий $\mathrm{F}_{4}$, полученных методом индивидуального отбора из гибридных популяций от скрещивания сортов пшеницы с синтетическими линиями селекции СІММҮТ. Посев питомника СП-1 проводили вручную рендомизированными блоками с группой стандартов Памяти Азиева, Дуэт, Элемент 22 в 3-х кратной повторности. Генотипирование синтетиков и линий яровой пшеницы осуществляли в «LGC Genomics (Beликобритания) с использованием 42 KASP-маркеров, в том числе 12 маркеров, сцепленных с генами, контролирующими размер и массу зерновки. 
Результаты. По результатам фенотипирования 2016-2018 гг. синтетических линий по комплексу хозяйственно-ценных признаков сформированы 2 набора линий: яровые синтетические формы - 48 линий и озимые 14 линий. Отбор селекционного материала с помощью КАSP-маркеров позволяет повысить точность отбора нужных генотипов и открывает новые возможности в маркер-ориентированной селекции для экономии времени и средств на создание новых сортов [3, 4].

Фенотипирование и генотипирование синтетических линий, а также полученного на их основе исходного материала, осуществлялось в соответствии, с указанной ниже схемой (рисунок). В 2016 г. проведены рекогносцировочные скрещивания яровых синтетических линий с реестровыми сортами Памяти Азиева и ОмГАУ 90, получено более 30 гибридных популяций, из которых путем индивидуального отбора выделено 207 линий, изученных в СП-1. Данные линии в 2018 г. были генотипированы с использованием 42 KASP-маркеров в лаборатории LGC-genomics.

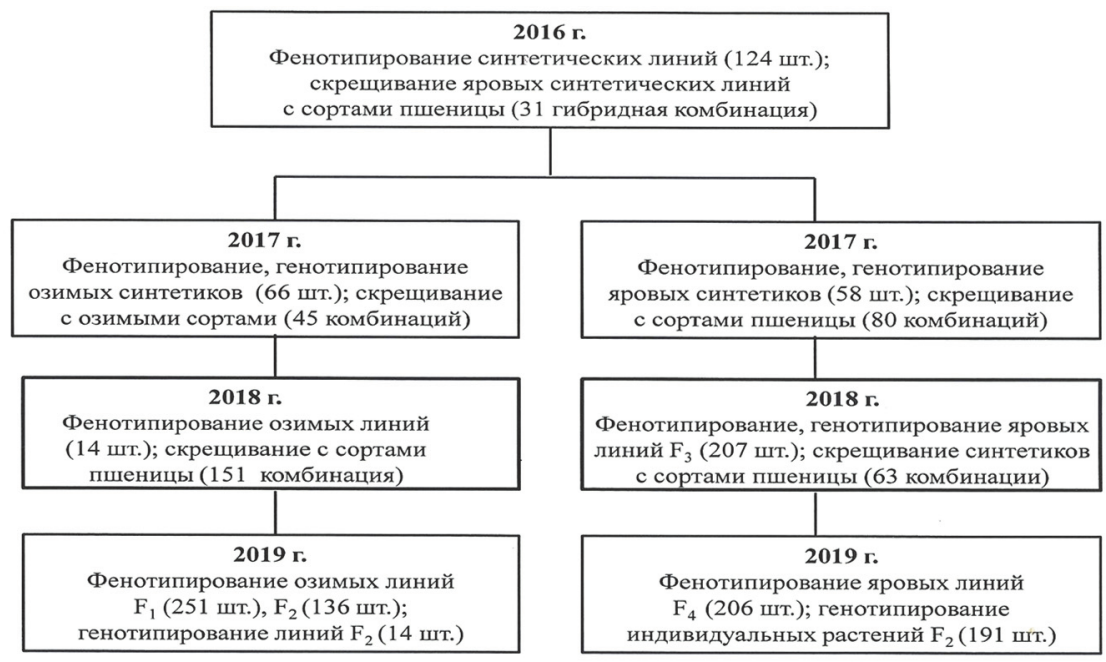

Рисунок. Скрещивания синтетических линий с сортами пшеницы, движение гибридных популяций в селекционном процессе, генотипирование селекционных линий.

В 2019 г. в питомнике СП-1 изучено 147 линий $\mathrm{F}_{4}$, полученных от скрещивания синтетической пшеницы селекции СІММYТ с реестровыми сортами яровой пшеницы Памяти Азиева и ОмГАУ 90 (таблица). Отдельные гибридные комбинации представляют интерес в качестве исходного материала в селекции на повышение урожайности, в частности, Aisberg/ Ae.sq.(369) // ОмГАУ 90, Ukr-Od.1530.94 / Ae.sq.(1027) // Памяти Азиева. 
Выделены линии данных комбинаций по основным компонентам продуктивности растений: числу колосков главного колоса - №9-4 UkrOd.1530.94 / Ae.sq.(1027) // Памяти Азиева (21,5 шт.); числу зерен главного колоса - №9-4 Ukr-Od.1530.94 / Ae.sq.(1027) // Памяти Азиева (56,1 шт.); числу зерен с растения №1-20 Ukr-Od.1530.94 / Ae.sq.(310) // ОмГАУ 90 (84,1 шт.); массе главного колоса - №9-4 Ukr-Od.1530.94 / Ae.sq.(1027) // Памяти Азиева (3,31 г); массе зерна растения - №8-23 Aisberg/ Ae.sq.(369) // ОмГАУ 90 (2,77 г); продуктивности растений - №8-31 Aisberg/ Ae.sq.(369) // ОмГАУ 90 (77,6 г/п.м), №8-34 Aisberg/ Ae.sq.(369) // ОмГАУ 90 (73,1 г/п.м), №9-1 Ukr-Od.1530.94 / Ae.sq.(1027) // Памяти Азиева (74,6 г/п.м).

Таблица - Линии яровой мягкой пшеницы, созданные с участием синтетических форм, СП-1, 2019 г. (в среднем на гибридную комбинацию)

\begin{tabular}{|c|c|c|c|c|c|c|c|}
\hline $\begin{array}{c}\text { № } \\
\Pi / \Pi\end{array}$ & 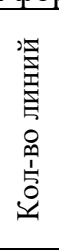 & Гибридная комбинация & 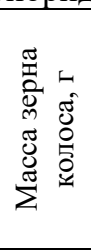 & 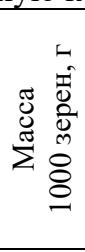 & 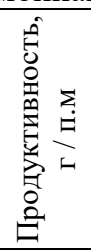 & $\begin{array}{l}d^{0} \\
\text { aे } \\
0 \\
5 \\
0\end{array}$ & 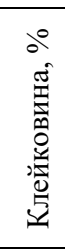 \\
\hline \multicolumn{3}{|c|}{ Памяти Азиева, среднеранний стандарт } & 1,23 & 31,4 & 31,5 & 15,3 & 27,9 \\
\hline \multicolumn{3}{|c|}{ Дуэт, среднеспелый стандарт } & 0,99 & 24,1 & 29,2 & 15,6 & 28,0 \\
\hline \multicolumn{3}{|c|}{ Элемент 22, среднепоздний стандарт } & 2,37 & 37,7 & $\mathbf{5 1 , 5}$ & 17,2 & $\mathbf{3 3 , 9}$ \\
\hline \multicolumn{3}{|c|}{ ОмГАУ 90} & 1,47 & 27,7 & 31,8 & 14,9 & 25,9 \\
\hline 1 & & $\begin{array}{l}\text { Ukr-Od.1530.94 / Ae.sq.(310) // } \\
\text { ОмГАУ } 90\end{array}$ & 1,49 & 29,5 & 33,2 & 15,6 & 28,2 \\
\hline 2 & & $\begin{array}{l}\text { Ukr-Od.1530.94 /Ae.sq.(392) // } \\
\text { ОмГАУ } 90\end{array}$ & 1,51 & 34,1 & 35,2 & 16,3 & 30,1 \\
\hline 3 & & $\begin{array}{l}\text { Aisberg/ Ae.sq.(511)// } \\
\text { Памяти Азиева }\end{array}$ & 1,22 & 33,3 & 29,8 & 15,0 & 27,8 \\
\hline 4 & 5 & Aisberg / Ae.sq.(511) // ОмГАУ 90 & 1,24 & 35,5 & 31,3 & 17,0 & 30,8 \\
\hline 5 & & Aisberg/Ae.sq.(369) // ОмГАУ 90 & 2,02 & 36,8 & 55,1 & 16,9 & 32,4 \\
\hline 6 & 19 & $\begin{array}{l}\text { Ukr-Od.1530.94 / } \\
\text { Ae.sq.(1027)// ОмГАУ } 90\end{array}$ & 1,52 & 33,1 & 36,5 & 16,4 & 30,8 \\
\hline 7 & 5 & Pandur / Ae.sq.(223) // ОмГАУ 90 & 1,51 & 34,7 & 39,1 & 16,4 & 30,3 \\
\hline 8 & 18 & $\begin{array}{l}\text { Ukr-Od.1530.94 / } \\
\text { Ae.sq. (1027) // Памяти Азиева }\end{array}$ & 1,71 & 35,7 & 42,4 & 16,1 & 30,9 \\
\hline 9 & 10 & $\begin{array}{l}\text { Ukr-Od.1530.94 / } \\
\text { Ae.sq.(458) // Памяти Азиева }\end{array}$ & 1,52 & 37,9 & 40,0 & 16,7 & 32,5 \\
\hline 10 & 10 & $\begin{array}{l}\text { Ukr-Od.1530.94 / } \\
\text { Ae.sq.(458) // ОмГАУ } 90\end{array}$ & 1,27 & 33,2 & 33,1 & 16,8 & 32,3 \\
\hline 11 & 10 & $\begin{array}{l}\text { Pandur / Ae.sq.(409) // } \\
\text { Памяти Азиева }\end{array}$ & 1,12 & 32,2 & 29,2 & 15,9 & 29,9 \\
\hline 12 & 9 & Pandur / Ae.sq.(409) // ОмГАУ 90 & 0,89 & 32,4 & 25,0 & 14,9 & 27,5 \\
\hline 13 & & $\begin{array}{l}\text { Aisberg / Ae.sq.(369) // Demir /3/ } \\
\text { ОмГАУ } 90\end{array}$ & 1,47 & 37,6 & 37,5 & 16,2 & 30,9 \\
\hline
\end{tabular}


Данные линии существенно превышали по продуктивности стандарт Элемент 22 (51,5 г/п.м). Линии, полученные путем гибридизации с синтетической пшеницей, имеют большое селекционное значение как источники для улучшения качества зерна яровой пшеницы. По содержанию белка и клейковины в зерне выделены линии гибридных комбинаций Ukr-Od.1530.94 / Ae.sq.(458) // Памяти Азиева - 16,7 и 32,5\% соответственно, №13-6 UkrOd.1530.94 / Ae.sq.(458) // ОмГАУ 90 - 16,8 и 32,3\%.

Для ускорения селекционного процесса и повышения эффективности отбора нужных генотипов линии, полученные на основе синтетической пшеницы, генотипированы с использованием 42 KASP-маркеров. Например, ген $T a G S-D 1$, контролирующий размер и массу зерновки, был идентифицирован у 74,4\% синтетических линий СІММYТ и 88,9 \% линий японских синтетиков, доля сортов-носителей данного гена из России и Казахстана в питомнике ОмонГАИ составила 34,7 \%. У линий $\mathrm{F}_{4}$ №8-23, №8-31, №8-34 гибридной комбинации Aisberg/ Ae.sq.(369) // ОмГАУ 90, выделенных по продуктивности растений, данный ген присутствует в генотипе, тогда как у стандартов (кроме Памяти Азиева) и ОмГАУ 90 ген TaGS-D1 не идентифицирован. Лучшие линии с генетическим материалом синтетической пшеницы переданы в контрольный питомник для дальнейшего изучения.

В заключении следует отметить, что с использованием синтетических гексаплоидов пшеницы с геномом Ae. tauschii создан ценный исходный материал, на основе генотипирования которого KASP-маркерами выявлены источники новых аллелей генов для расширения генофонда пшеницы и ускорения селекционного процесса выведения сортов яровой мягкой пшеницы с высокой урожайностью и качеством зерна.

Благодарности: Данное исследование проведено при финансовой поддержке РНФ (проект № 16-16-10005).

\section{Список литературь}

1. Оценка линий синтетической пшеницы (Triticum durum/Aegilops tauschii) по вегетационному периоду и устойчивости к болезням / В.П. Шаманин [и др.] // Вавиловский журнал генетики и селекции. - 2017. - 21(3). - С. 347-353.

2. Морфометрические параметры корневой системы и продуктивность растений у синтетических линий яровой мягкой пшеницы в условиях Западной Сибири в связи с засухоустойчивостью / В.П. Шаманин [и др.] // Сельскохозяйственная биология. 2018. - T.53. - № 3. - С. 587-597.

3. Хлесткина Е.К. Молекулярные маркеры в генетических исследованиях и в селекции / Е.К. Хлесткина // Вавиловский журнал генетики и селекции. - 2013. - Т. 14. - № 4/2. - C. 1044-1054.

4. Evaluation and haplotype analysis of elite synthetic hexaploid wheat lines for resistance to hessian fly / G.T. Yu [et al.] // Crop Sci. - 2012. - V. - 52. - P. 752-763.

5. Genetic contribution of synthetic hexaploid wheat to CIMMYT's spring bread wheat breeding germplasm: scientific reports / U. Rosyara [et al.]. - 2019. - V. 9. - P. 12355. 
6. Genetic diversity and population structure analysis of synthetic and bread wheat accessions in Western Siberia / M. Bhatta [et al.] // Journal of applied genetics. - 2019. - V. 60 (3-4), P. 283-289.

7. Kihara H. Discovery of the DD analyser, one of the ancestors of Triticum vulgare / H. Kihara // Agric. Hort. - 1944. - V.19. - P. 889-890.

8. McFadden, E.S., Sears, E.R. The artificial synthesis of Triticum spelta / E.S. McFadden, E.R. Sears // Rec. Genet. Soc. Am. - 1944. - V.13. - P. 26-27.

\section{Молекулярно-генетические основы для направленной селекции на содержание полифенольных соединений в зерне ячменя}

Шоева О.Ю. ${ }^{1 *}$, к.б.н., с.н.с., Стрыгина К.В. ${ }^{2}$, Глаголева А.Ю. ${ }^{1}$, Гордеева Е.И. ${ }^{1}$, Вихорев А.В. ${ }^{1}$, Кукоева T.В. ${ }^{1}$, Хлесткина Е.К. ${ }^{1,2}$

${ }^{1}$ Института циитологии и генетики СО РАН (ИЦиГ СО РАН), Новосибирск, Россия,

${ }^{2}$ Всероссийского института генетических ресурсов растений имени Н.И. Вавилова (ВИР), Санкт-Петербург, Россия.

*e-mailolesya_ter@bionet.nsc.ru

Состав и количество полифенольных соединений в зерне ячменя определяют его изелевое использование. Направленное создание новых сортов с заданными паттернами полифенольных соединений невозможно без знаний об их синтезе и его генетической регуляция. В представленной работе были идентифицированы гень, контролирующие биосинтез антоциановых пигментов и проантоцианидинов в зерне ячменя и установлены особенности их функционирования. Полученные данные используются в селекции на содержание и состав полифенольных соединений в зерне ячменя.

Ключевые слова: Hordeum vulgare, антоцианы, проантоциианидины, меланинь функциональное питание, пивоварение, маркер-ориентированная селекция.

\section{Molecular-genetic basis for directed breeding for polyphenol content in barley grain}

Shoeva O.Yu., Senior Researcher, the FRC Institute of Cytology and Genetics SB RAS, Novosibirsk, Lavrentjeva ave., 10,*e-mail: olesya_ter@bionet.nsc.ru

The content and composition of polyphenolic compounds in barley grain determines its objective application. The targeted creation of new varieties of barley with given patterns of polyphenolic compounds is impossible without knowledge of their synthesis and its regulation. In the presented study, the regulatory genes that control synthesis of anthocyanin pigments and proanthocyanidins in barley grain 